\title{
Between a rock and a hard place: the need for and challenges to implementation of Rights Based Fisheries Management in small- scale fisheries of Southern Lake Malawi
}

Hara, Mafaniso and Njaya, Friday

\begin{abstract}
There has been a decline in commercially valuable fish species, especially the Chambo (Oreochromis spp), in southern Lake Malawi. Although there might be lack of reliable and scientifically backed evidence, most experts and experienced fishers concur that productivity of most fish stocks in the area is much below par compared to their productivity about two to three decades ago. This leads to the hypotheses that the fish stocks are generally over-exploited. This trend will continue or their productivity will remain at these depressed levels unless appropriate measures are taken. This article argues that Rights Based Management (RBM) could hold the best hope for moving towards sustainable fisheries management in the southern Lake Malawi (Southeast and Southwest Arms) area while recognizing the need for a broad human rights approach for fishing communities. Even then, the implementation of the RBM approach will not be easy given the historical developmental open access management approach and general unorganized characteristics of the small-scale fisheries sector. Of note is that comanagement was introduced in area in the early millennium as part of attempts to strengthen user fishing rights, local accountability and stewardship - with mixed results.
\end{abstract}

\section{Introduction}

About 20\% of Malawi's 118,484 km2 constitutes water. As such, fishing is an important economic sector and contributes to the livelihoods of hundreds of thousands of Malawians. In addition, fisheries provide food and nutritional security to both the rural and urban poor. It is estimated that the fishing sector contributes about $4 \%$ to the Gross Domestic Product (FAO 2014). While fish contributed 70\% of the animal protein in the diets of Malawians in the 1970s, this has declined as a result of declining catches and population growth. As a result, Malawi's per capita fish supply had fallen from $14 \mathrm{~kg}$ in the 1970 s to about $5.7 \mathrm{~kg}$ per person per year by 2011, a 60\% decline (FAO, 1992, 2012). This implies a serious decline in fish protein supply to the nation, especially for the vulnerable poor that rely on fish as a cheaper source of protein. In addition, the sector employs nearly 60,000 fishers and over 500,000 other people in secondary and support services (Department of Fisheries (DoF), 2013a). Since 1974, the estimated total annual 
fish yield for all waters in Malawi has increased gradually to an estimated 119,0oo tons, $60 \%$ of which is comprised of the lake sardine usipa Engraulicypris sardella (DoF, 2013b). Meanwhile, landings of the most valuable species such as chambo (Oreochromis Nyasalapia) have declined dramatically (Banda et al., 2005; Hara, 2006; Weyl et al., 2010) despite large increases in fishing effort (DoF, 2013a). This implies an increase in fishers investing in engines for offshore fishing, especially for usipa. The most important fishing gears (in terms of catches and employment) are offshore open-water seines and gillnets (Weyl et al., 2004; Hara, 2011). The large landings of usipa, resulting in the general overall increase in national total catches, masks the problem that is being experienced with decreased catch rates for more valuable species, largely as a result of the uncontrolled increase in fishing effort as the current management policy does not include effort limitations other than the use of input technical regulations (Hara, 2006; Weyl et al., 2010; Tweddle et al., 2015).

This paper aims to identify challenges for introducing a Rights Based Management (RBM) approach for recovery of the declined chambo stocks and achieving sustainable utilization of the fisheries resources in general in the southern Lake Malawi. We believe that there is need for a governance approach that will effectively regulate both fishing effort and output to move towards sustainable utilization of fisheries in Malawi, smallscale fisheries sector lands over $95 \%$ of the catch and also employs more than $95 \%$ of the people directly involved in fishing (Hara, 2011). Southern Lake Malawi is the most productive area of the lake, which also attracts the highest concentration of fishing effort on the Lake (FAO, 1993; Hara, 2006; Kanyerere et al., 2010; DoF, 2013a). We have used statistical data routinely collected by the DoF for the area and findings from national stakeholder workshops conducted in 2011 and 2012 as part of revising Malawi's Fisheries Policy (GoM, 2012). In addition, the authors were Mangochi District Fisheries Officers in the 1990s and 2000s and have had long and continued involvement and experience with fisheries management in the area and Malawi as a whole for the last three decades.

We acknowledge that the RBM approach needs to be based on the recognition and application of accompanying basic human rights that address the general social and economic vulnerability of fishing communities and that "vulnerable people do not make the most effective and motivated resource stewards" (Allison et al., 2012). The Malawi Growth and Development Strategy (MGDS), the overarching operational medium-term strategy for Malawi, states its main objective as being poverty reduction and achieving the Millennium Development Goals (MDGs) through sustainable economic growth and infrastructure development (World Bank, 2012). The strategy recognizes the need to invest in social development through education, health, good governance and the need to protect the most vulnerable. In addition, Malawi is party to internationally accepted principles and conventions such the Universal Declaration of Human Rights, and the International Guidelines for Securing Sustainable Small- Scale Fisheries in the Context 
of Food Security and Poverty Eradication (FAO, 2013). All these urge and allude to the need for a human rights approach to natural resource and fisheries governance. While we recognize the need for such a 'rights based approach' (FAO, 2005) that would secure all other basic human rights for vulnerable groups in Malawi including fishing communities, we argue that Malawi's historical approach to fisheries management that has been based on open access and limitless output has set the fishery on a trajectory that can only have poor outcomes for the fishery and the dependent communities. There is need for an approach that could curtail such ominous 'tragedy' (Hardin, 1968) and set the fishery on sustainable utilization path if the fishery is to continue providing for human-wellbeing and economic benefits. We argue that a RBM, as a policy and organizing approach, has the potential to provide a solution to the current management problem despite the challenges of implementing such an approach.

We also acknowledge the arguments that have been put forward by Jul Larsen et al. (2003) for leaving most fisheries in southern Africa as open access as they provide a 'labour buffer' and 'safety net' for poor rural communities, and also those by Béné et al. (2010) that wealth-based approaches should not to be introduced in small-scale fisheries of developing countries unless economic conditions are in place for "forcing people out of the fisheries sector" (Béné et al., 2010: 349) as the sector plays an important 'welfare function' for rural unemployed communities. Rather than using RBM as a neoliberal rent maximisation management and organising principal, we are arguing for the use of RBM as a principled approach for putting an end to negligent open access that has been the approach in Malawi. As Jul Larsen et al. (2003: 89) acknowledge "There is no doubt that the commons can lead to ecological tragedies"

\section{Rights Based Management}

RBM is based on the idea of extending exclusive 'use rights' to a defined group of fishers (Organization for Economic Cooperation and Development (OECD), 1997; Shotton, 2000 Hatcher and Read, 2001; Arnason, 2005). Rights in a fishery define a claim to a share in a fishery that is protected by law, and what particular actions a rights holder is legally authorized to undertake in extracting the benefits (Bromley, 2009; Sumaila, 2010). Property rights are supposed to provide for perpetuity, security, exclusivity and transferability (Edwards, 2000; World Bank, 2004; Gibbs, 2009; Ostrom, 2009) of a rights holder's share in a fishery. Presumably having secure and assured rights can increase the value of the right and influence positive behavior towards regulations, thereby improving the long-term biological, social and economic sustainability of the resource (OECD, 1997; Shotton, 2000; Arnason, 2005; Sumaila et al., 2008; World Bank, 2009). The initial critical issue in RBM for administrators and fishers is the basis for eligibility for allocation of a right. The most common approach is 'catch history'

\section{http://repository.uwc.ac.za}


(Copes and Pálsson, 2000; Edwards, 2000; Arnason, 2005; FAO, 2005). However, other criteria need to be applied to protect culturally and economically vulnerable groups such as women and crewmembers when allocating rights. Thus, the issue of equity arises with regard to the allocation of exclusive use rights since such rights define who can and cannot participate in the fishery, given that decisions about such rights may be very difficult to reverse once these have been allocated (Eythórsson, 2000; Clark et al., 2010). Three approaches have been used for RBM, namely Individual Transferable Quotas (ITQs), licensing limits, and Territorial User Rights in Fisheries (TURF) (Ruddle et al., 1992; Eythórsson, 1996; OECD, 1997; Christy, 2000; Grafton et al., 2007; Costello et al., 2008).

Under the ITQs approach, the annual Total Allowable Catch (TAC) is divided into shares, that are distributed among the selected rights holders (Essington, 2010; Sumaila, 2010). One of the aims of introducing ITQs is to reduce over-capitalization and excess effort, and also improved adherence to a rights holder's quota share (Sumaila et al., 2008; World Bank, 2009). In most countries where ITQs have been implemented, it has been demonstrated that this approach can increase economic efficiency (Grafton, 1996; Dewees, 1998; World Bank, 2009; Sumaila, 2010). At the same time one of the negative consequences of ITQs is that they can result in negative social costs especially on coastal communities that might be solely dependent on the fishing industry (McCay, 1998; Hara, 2013). For example, in Iceland, small fishing communities lost a large relative share of the quota resulting in increased financial problems and unemployment (Arnason, 2005). In Norway, the number of people employed in the fishing industry declined ten-fold from 120,000 in 1945 to 12,000 in 2009 as a result of enormous technical improvements and economic rationalization of the fishing industry (Béné et al., 2009). In this case (Norway), this change had been cushioned by the fact that people could move to other sectors of the economy. Davis and Ruddle (2012) point out that the market based and property rights approach, with its genesis in neoliberalism is not really the universal leveler of the playing field and equaliser of shared benefits as we are made to believe. The authors argue that the approach ignores the underlying politicaleconomic dynamics in small-scale fisheries around power differentials, social class inequities, gendered relations, cultural factors, etc. that are the lived reality of most fisher communities. According to Davis and Ruddle (2012), the approach is likely to "merely deepen penetration of neoliberal values and, by so doing further define and advance social class formation and differentiation in families and local societies" (Davis and Ruddle, 2012; 251). Thus administrators need to weigh the benefits and negative impacts of ITQs when implementing these and that they should not be seen as the panacea for solving all fisheries management problems (Gibbs, 2009; Pinkerton and Edwards, 2009; Clark et al., 2010; Essington, 2010), particularly in small-scale fisheries in developing countries (Davis and Ruddle, 2012; Béné et al., 2010). Despite the doubts and problems about the applicability of ITQs for managing multi-species and data poor 
fisheries that are typical of small-scale fisheries in developing countries (Pauly, 1996; Sumaila, 2010), new methods of setting catch limits for data-poor fisheries (Carruthers et al., 2014; Newman et al., 2015) provide hope that such problems could be overcome.

The limited licensing system tries to limit access to a fishery by limiting the number of fishery participants (Townsend, 1990; Sanchirico and Wilen, 2002). This approach is suited to a fishery with many ports or offshore (trans-shipment) opportunities to offload catch, which would make a quota system difficult to enforce. The basic problem with this system is that it does not remove the 'race for fish' unless it is used with other measures such as limiting vessel power, days at sea or other measures that could control fishing intensity.

Unlike species-based rights systems such as ITQs, TURFs are place-based rights that allocate some or all resources within a designated coastal zone to specified communities (Ruddle et al., 1992; Wilen et al., 2012). The growing interest in TURFs is based on their recognized potential as a management tool for fisheries threatened by problems of open access and high management costs especially for remote, scattered, multi-gear, multispecies and dynamic small-scale fisheries (Asada et al., 1983; Wilen et al., 2012).

In Malawi, participatory fisheries management (co-management) was supposed to extend secure access, harvesting, and management rights (Schlager and Ostrom. 1992) to fishing communities (Hara et al., 2002; Weyl, 2008; Béné et al., 2009; Njaya, et al., 2012). The thinking was that by extending greater and more secure rights to fishers, this would improve fisheries management and reduce transaction costs. It was also expected that later exclusion rights could be included in these other rights.

While advocacy for RBM has strong theoretical arguments, it is also increasingly realized that this underplays the complex relationship between poverty, resource access, and the wider social, economic and political context within fishing communities (Ratner et al., 2014). There is thus a growing call for fisheries policy reform approaches that include the realization of basic human rights for fishing communities in complement to fishing rights (Ratner and Allison, 2012). For most fishing communities, issues about health, lack of infrastructure, food security, access to education, etc. are articulated as being equally or even more important than access rights to fisheries (Barratt, 2012; Mills et at., 2011; FAO, 2012; International Collective in Support of Fishworkers (ICSF), 2007). Thus the 'rights-based approach' to development argues that human rights ought to be an integral part of development initiatives and outcomes as stipulated by international human rights norms and conventions (Ratner et. al., 2014). According to Suárez (2012), human rights apply to all human beings universally and, are indivisible and interrelated. Based on international treaties and conventions, human rights are intent on protecting human dignity across sex, origin, race, religion or any other status. Unfortunately, rights to natural resources are not specifically recognized as a universal

\section{http://repository.uwc.ac.za}


human right, resulting in continued commoditization and marketization of natural resources at the expense of communities whose livelihoods might solely depend on such resources (Suárez, 2012; Sunde and Sharma, 2012). Sunde and Sharma (2012; 283) point out that the 'human rights framework' has helped deepen the understanding among activists that the "notion of 'citizenship' for poor fishing communities is inextricably tied to a range of political and civil freedoms, but that these freedoms only find meaning and expression through social, cultural and economic rights." Sharma (2011) argues that realizing human rights for fishing communities is an obligation for all fishing nations and that the framework provides strong basis for citizens to make claims on their states for their basic human rights and also for holding states accountable to their duties. In addition, a human rights approach draws attention to the analysis of institutions and power structures that influence access to resources and allocation and, how these impact on livelihoods and community wellbeing and, how these should be reformed (Ratner et al., 2014).

\section{Southern Lake Malawi}

The southern end of Lake Malawi (Figure 1) comprises of the Southeast Arm (SeA) and Southwest Arm (SwA). The two areas are the most productive fishing area of the Lake (Hara, 2006; Weyl et al., 2010). In recent years the area has accounted for about $60 \%$ of the annual fish landings from Lake Malawi even though it represents only $10 \%$ of the total surface area of the Lake (Kanyerere et al., 2010). 


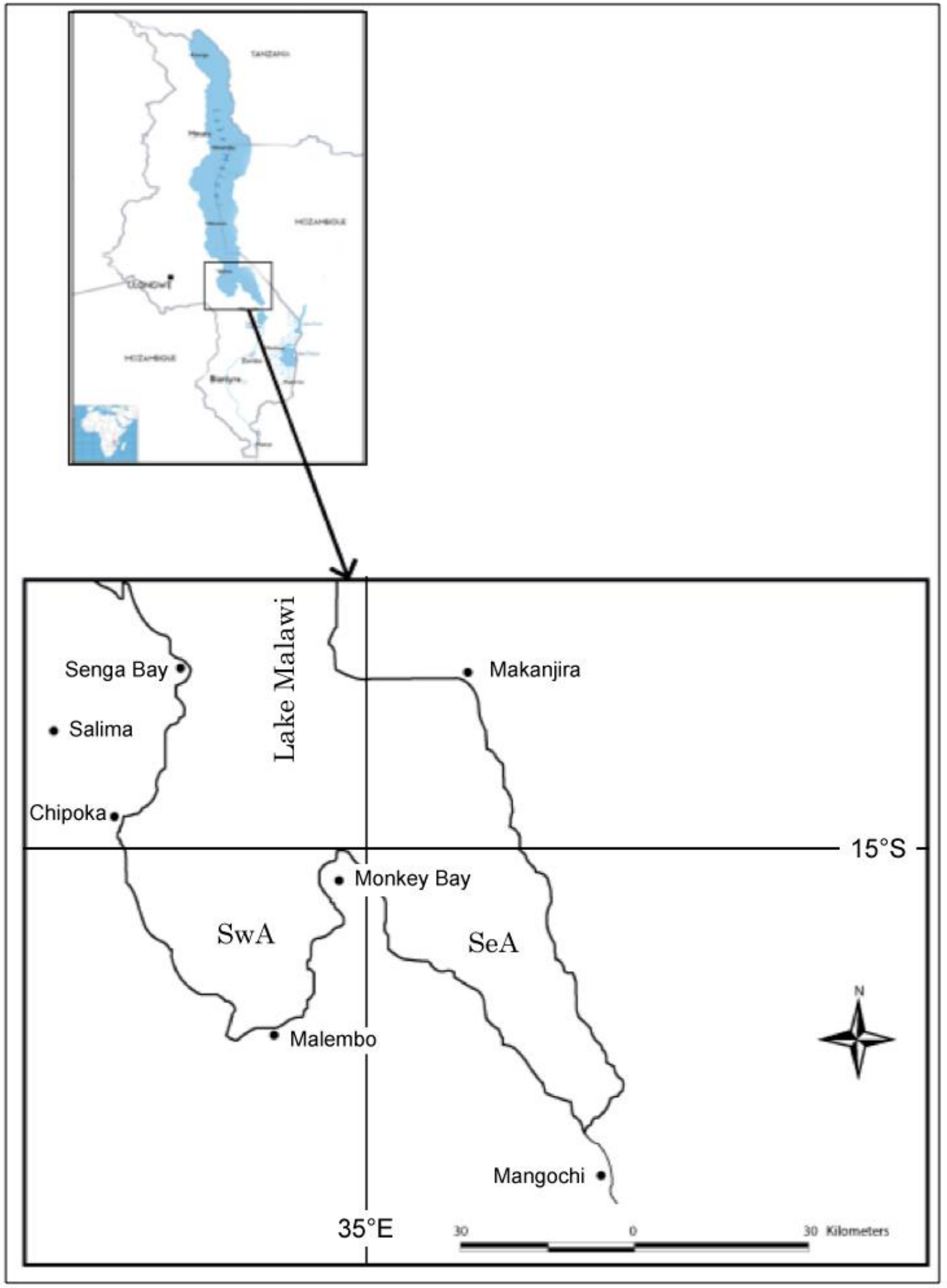

Figure 1. Southern Lake Malawi showing the Southeast and Southwest Arms 


\subsection{Production and effort trends}

Landed catch increased by over 200\% during the period between 2002 and 2011 (Figure 2). Just like the national trends, this phenomenal increase in fish production had largely been as a result of huge increases in usipa catches, a highly reproductive, fast-growing, and density- and environment- dependent cyprinid (Lewis and Tweddle, 1990; Thompson et al., 1996; Thompson and Allison, 1997). In comparison, the catches of the commercially high value species such as chambo had declined drastically during the same period (Banda et al., 2005; Hara, 2006; Weyl et al., 2010).

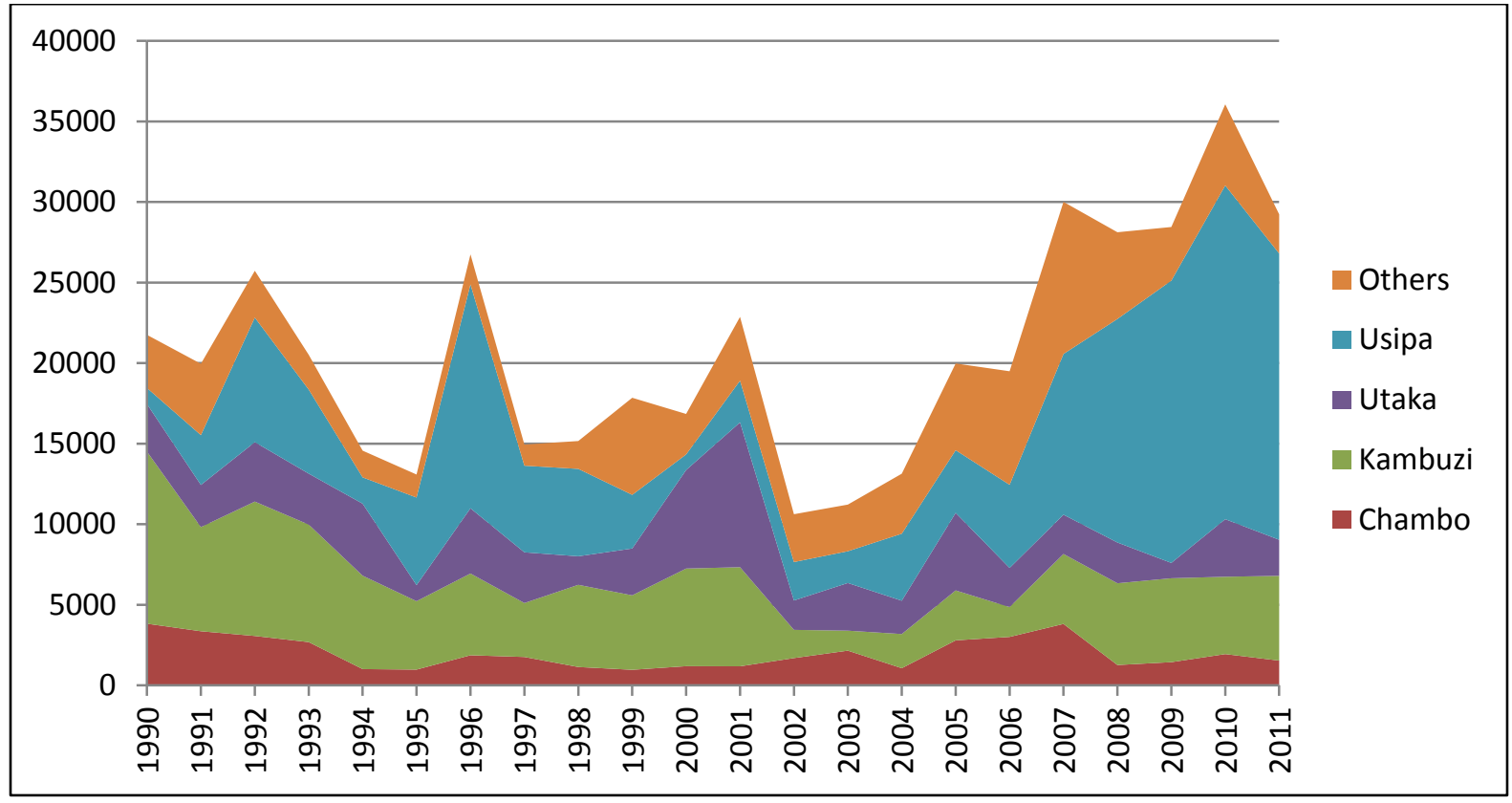

Figure 2. Estimated total production from SeA and SwA for years 1990 to 2011 (Source: GoM 2013b)

\subsection{Catch trends for the key species - chambo and usipa}

High fishing effort and the development of new destructive techniques have redcuced catches of high value species and have also resulted in changes in fish species composition (Turner et al., 1995; Weyl et al., 2005; Hara, 2006; Weyl et al., 2010). Environmental degradation has also contributed to localized over-exploitation of some species (Turner et al., 1995; Mkanda, 2000; Hecky et al., 2003; Delaney et al., 2007). As a result a number of taxa that were historically abundant in Southern Lake Malawi prior to the mid-1970s are either locally extinct or are caught in substantially lower amounts (FAO, 1993; Turner, 1995; Banda and Tomasson, 1997; Banda et al., 2005). While the 
Chambo dominated the catch composition until the early 1990s, small haplochromines had become increasingly important thereafter (Hara, 2006; Weyl et al., 2010). The contribution of the Chambo to total production from the area declined from $70 \%$ in 1982 to less than $5 \%$ in the early 2000 (JICA, 2005). Respondents from interviews and the workshops attributed the decline in chambo productivity to the following factors: too many fishers; inshore trawling; use of under-meshed gillnets; kauni , kambuzi seines and nkacha seines. Small-scale fishers also mentioned non-compliance with regulations such as closed seasons and weak DoF's enforcement capacity as reasons for the decline of the chambo (GoM, 2012). The decrease in catches of the commercially valuable species like chambo has been compensated by the increase in catches of this low value species.

Chirimila, which is used to catch both usipa and utaka (Copadichromis spp) and chambo (kauni), was the dominant gear catching $81 \%$ of the total fish landings from the area in 2011 (Fig. 2). In general, fishers targeted usipa much more than utaka because of the far better catches of the former compared to the latter for similar effort. Gillnets mainly of ngongongo type were the second most important gear. The DoF field staff reported that there had been an increase in use of ngongongo in the past decade as a result of decline in productivity of normal gillnets. While fishers argue that the net targets utaka, the fear is that the net is also used to catch under-sized chambo (Weyl et al., 2004).

\section{Reasons for decline in productivity of the fishery}

A number of reasons are attributable to the decline in productivity of the fishery in Southern Lake Malawi if we ignore the continuing healthy catches of usipa. These are: excess effort; small-scale fishery characteristics; weak monitoring, control and surveillance; inability to demonstrate the real value of the fishery; lack of limits on effort and output; and overlapping policy, legislation and institutions.

\footnotetext{
${ }^{1} \mathrm{~A}$ method of catching chambo at night by light attraction using the chilimira

${ }^{2} \mathrm{~A}$ beach seine with mesh sizes ranging from a few $\mathrm{mm}$ to $25 \mathrm{~mm}$ at the bunt and headline length 50 to $700 \mathrm{~m}$ with depth varying between 2 and $12 \mathrm{~m}$. It is normally cast from the beach using a single boat and then pulled from both sides simultenously by two sets of 6 to 20 people. When operated behind a chambo seine net or another kambuzi seine of longer headline length and bigger mesh sizes, it is then refered to as chalira (FAO, 1993).

${ }^{3}$ Open water seine net that was developed at Lake Malombe in the late 1980s and introduced Lake Malawi in the 1990s.
} 


\subsection{Excess effort}

The biggest cause of decline in productivity of the fishery is attributable to excess effort (Banda et al., 2005; Hara, 2006; Wely et al., 2010; Bell et al., 2012; Song and Chuenpagdee, 2013). Historically, Malawi's fisheries have been managed from a developmentalist and frontiers approach. In other words, government has regarded fishing as an economic activity that should be open to all who are able to and can afford to invest and enter the fishery (GoM, 1973). Fishing in this sense was seen as a new economic frontier, of unlimited potential for expansion, to conquer and bring into the fold of activities that could effectively contribute to economic development and increased fish protein supply. This has not changed and entry to small-scale fisheries remains open to all and levels of investment and fishing effort uncontrolled (Hara, 2006; Weyl et al., 2010). The only regulatory controls that are officially in place are technical (input) regulations such as mesh-size limits, closed season for chambo, and gear length limits for some fishing gears. All these are poorly enforced in any case.

Excess effort is made worse in that the commercial fishing sector also fishes in the same area and also targets the same species (kambuzi, utaka and chambo) as the small-scale sector (Weyl et al., 2005). In 2007, 15 trawl units were licensed composed of eight deep water (bottom) trawl units, four mid-water trawl units and three shallow water trawl units. By 2012, the number had grown to 24 with the same number of deep water and mid water trawls and nine additional shallow water trawl units. Almost all these have been allocated to fish in the Southern Lake Malawi area, with only three units allocated to fish in the central lake districts - further increasing the effort on the fishery. Furthermore, most of the trawl units use engine power of over 45hp which is illegal. Other than limited licensing and allocation to specific fishing zones, output regulations are not used as a management tool in the commercial sector either. Generally, there has also been a decline in recorded catches from commercial trawling since its introduction in 1975 (Turner, 1995; Turner et al., 1995; Weyl et al., 2005; DoF, 2013b).

\subsection{Artisanal fishery characteristics}

One of the key characteristics of the small-scale fisheries sector is that in most instances, gear owners find their own sources of investment. The key source of investment used to be earnings from foreign migrant labor (Chirwa, 1995; Hara and Jul Larsen, 2003). Even currently, most people who invest in the small-scale sector do not derive their capital from government programmes or formal financial institutions such as banks. In addition, fishers invent and develop their own fishing methods. For example, the nkacha, kauni and kandwindwi fishing methods had been developed by fishers on their own, mainly as innovations on existing methods to take advantage of new species or to improve declining catches of the same species. The chilimira was developed by Tonga 
fishers from Nkhata Bay, and introduced to the central and southern Lake Malawi areas by the same ethnic group through migration (Kapeleta, 1973). The implications for this are two-fold: firstly, government has little leverage on what methods can be used in the small-scale fishery since it does not provide the investment and secondly, government has no hand in the development of the fishing methods and their innovation. The consequence of the latter is that the government is always lagging behind in terms of what new fishing methods are being invented, developed and instituted by the fishers. By the time these come to light and government becomes aware of them, their use would have become so widespread that it becomes difficult to control if these are deemed to have illegal specifications since they might not necessarily be illegal in the statutes. The usual tactic by government has been to ban such new 'illegal destructive' methods. In this context, government tried to ban the nkacha from Lake Malawi, the use of kauni and lately the use of kandwindwi and ngongongo without much success.

\subsection{Weak Monitoring Control and Surveillance (MCS)}

Monitoring and enforcing fishing regulations offshore requires patrol boats and resources to run these. The DoF lacks the capacity to enforce the regulations due to inadequate resources. Monitoring and controlling activities of fishers is made even more difficult in that artisanal fishers are not required to operate from specific points or harbors. Thus they can launch from and land anywhere they want. When the use of input and technical regulations is coupled with poor enforcement, this compounds the problem. Thus generally DoF is unable to enforce the existing regulations leading to rampant and widespread use of illegal fishing gears and methods.

${ }^{4}$ Gillnets with meshes sizes much smaller than the recommended size of $95 \mathrm{~mm}$ which fishers claim are used for catching utaka (Copadichromis spp) but are reputed to actually target undersized chambo.

${ }^{5}$ A gillnet in the form of a trawl with a long rope sometimes over $1,000 \mathrm{~m}$ long operated by several fishers as a beach seine. The method derives its name from the MV Kandwindwi, the biggest commercial trawler on Lake Malawi owned by MALDECO, a private fishing company. 


\subsection{Inability to demonstrate the real value of the fishery}

The issue of inadequate resources for research, data collection and MCS activities relates to the inability of the DoF to convince Treasury that it deserves more funding for fulfilling its mandated activities efficiently. Treasury mainly uses the amount of revenue that a department collects and contributes to the total government revenue collection, and also the value of its activities to the economy, as basis for calculating amount of funding that should be disbursed to that department ${ }^{1}$. The amount of revenue that the DoF collects and contributes to government revenue collection is seen as being too low to deserve more funding than it currently gets. The main source of revenue for the DoF is fishing gear license fees. The problem about the low revenue collection is related to two main issues; firstly, the Department is not able to collect the gear license fees from all available operating fishing gears. Although all fishers are supposed to license their gears annually, most do not since the DoF lacks the capacity to enforce this regulation strictly. As a result, most small-scale fishers behave as if annual gear license renewal is voluntary. They expect the DoF to go and collect the fees from their areas rather than going to the District Fisheries Office to pay the license fee on their own. In most instances, they will only pay if the DoF confiscates their gear and they have to pay the fees in order to retrieve the gear. A limited analysis for Mangochi showed that less than $20 \%$ of gear owners renew their annual licenses (Hara 2006). Secondly, the size of the fees for the various gear types is not based on cost recovery. As a result the value of the revenue collected has further fallen behind due to inflation and decline in the value of the Malawi Kwacha. Ideally, the level of license fees ought to be based on $100 \%$ cost recovery for all management activities.

Another issue is the valuation of the contribution of the fishing sector to the general economy's Gross Domestic Product. There is need to demonstrate the real value of the fishing industry. The department needs to collect systematic data on both raw fish value at the point of landing and also how this increases as the fish moves through the value chain. A second aspect of this valuation is the economic value of fishing businesses in terms of assets and operations. If one calculated the total asset value of boats, fishing nets, wages and capital assets and all revenues streams from fishing as business activities, this would give a clearer picture of the sector's contribution to the economy. The problem though is that most fishing units in the small-scale fisheries sector are not registered as businesses that should pay company tax and other government revenues such as personal tax. The historical attitude that fishing is a subsistence activity appears to be still prevalent negating proper evaluation of the sector and its position in the economy.

\footnotetext{
${ }^{6}$ Except for those departments that have social or security responsibilities such as Health, Social Welfare, Millitary, Police, etc.
} 


\subsection{Need to introduce limits on effort and output}

There are no limits on effort on the small-scale fisheries sector, and for both artisanal and commercial fisheries there are no limits on the amount of fish that the fishers and licensees are allowed to catch annually (Hara, 2006; Weyl et al., 2010). At the policy review workshops (GoM, 2012), most participants gave their biggest concern about the fishing industry as being the decline in catches. They gave the reason for the decline of the fishery as being excess effort (too many fishers, too many fishing boats and too many fishing gears). In addition it was pointed out that increased competition for fish coupled with poor enforcement of regulations has led to increased and widespread illegal fishing activities.

Reducing effort will require bold measures in two areas of management; introducing limits on effort in the small-scale fisheries sector and also introducing output controls in both sectors. In the small-scale sector, this would require putting in place routine methods and systems for estimating the resource biomass and thus MSY levels for key target species and then allocating limited fishing rights to achieve the requisite MSY effort. Currently, sampling survey systems (Catch Assessment Survey and Malawi Traditional Fisheries) are used to collect catch data in the small-scale sector. The assumption has been that such data could be used for calculating biomasses and then the MSYs for various key species. The problem is that the reliability of the data remains tenuous as the field staff that collect the data are poorly supervised and poorly remunerated. But the biggest problem is technical; even if the DoF obtained good time series data based on these surveys and was able to compute the biomasses and then MSYs for the key species, expecting the sector to keep within proposed MSY levels through the use of input and technical regulations without limits on fishing intensity and output would be very difficult.

\subsection{Policy, legislative and regulatory problems}

Management of the SeA /SwA and the catchment of the area falls under a number of departments, sectoral policies and legislations that include Fisheries/Aquaculture, Marine, Local Government, Environmental, Agriculture and Livestock, Tourism, Forestry, National Parks and Wildlife, Water and Land. These sectoral policies and legislations are usually in conflict with each other and overlap in jurisdiction (Weyl et al., 2010; Donda et al., 2014). For example, the Ministry of Agriculture is promoting use of water from the lake for irrigated agriculture (for example under the Green Belt Initiative (GoM, 2009)) and crop cultivation on river banks and lake shorelines in promotion of food security; the Ministry of Tourism promotes lakeshore development of holiday resorts, etc. Some of these agricultural practices and tourism developments result in loss of fish habitats along the shoreline and inshore areas and a change in 
hydrological regime of the lake and feeder rivers (Mkanda, 2000; Hecky et al., 2003; Weyl et al., 2010; Donda et al., 2014). Enforcement of fisheries regulations in some parts of the SeA/SwA falls under overlapping jurisdictions by DoF and the Department of National Parks and Wildlife since parts of Southern Lake Malawi form part of the Lake Malawi National Park.

While the Fisheries Conservation and Management Act (FCMA) of 1997 (GoM, 1997) has the necessary provisions to address the management and conservation of fisheries resources in all fishing waters of the country, the subsidiary legislation (Fisheries Conservation and Management Regulations of 2000 - GoM 2000) published in pursuance of the FMCA is not comprehensive enough to implement the Act. For example, regulations in the subsidiary legislation pertaining to gillnet fishing periods and times have been omitted, resulting in increased conflicts between the small-scale and commercial fishers. The closed season is discriminatory; i.e. it is only applicable to small-scale fishers' beach seines and not to commercial fishers. Also, there is no provision to accommodate or how to deal with the introduction of new fishing gears and techniques. Finally, the punitive measures are not prohibitive enough as to be deterrent.

Although Participatory Fisheries Management (PFM) is the recommended approach under the FCMA, the centralized management still under-lays the legislation as can be seen in some of provisions of the FCMA in terms of empowerment. For example, Sections 5(1) and 4(1) give powers to the Director of Fisheries to appoint members of the Fisheries Advisory Board and Honorary Fisheries Protection Officers. The Director is also empowered to develop local management plans that $\mathrm{s} / \mathrm{he}$ can subsequently unilaterally impose. Although in this process, the local communities should be formally consulted, they cannot influence change of the management plans despite the knowledge, experience, and interests they bring to participatory management. Issues of control of beaches, issuing of fishing licenses, and funding mechanisms for Beach Village Communities (BVCs) are not elaborated in the Act either. Thus although there is a provision for involving the local communities in fisheries management, the FCMA does not give real authority and responsibility to local level village administrations and/or BVCs as part of the devolution process. Related to PFM is administrative decentralization that is being implemented which could affect the way fisheries will be managed in future. It is not clear at the moment how PFM will function under administrative decentralization (Hara, 2008).

\section{Damned if you do, damned if you don't - is RBM the solution?}

The observed problems of managing small-scale fisheries in Malawi call for credible and effective action by the DoF in collaboration with all other stakeholders. If nothing is done the problem is likely to get worse. The problem is that the system of open access,

\section{http://repository.uwc.ac.za}


unlimited effort and unlimited output is so ingrained in fisher's historical perception and fishing practices that although they realize and acknowledge the excessive effort that is being applied in the fishery they have until now resisted the idea of limiting access, effort and output (GoM, 2012). They have in the past argued that they did not have any other sources of income and livelihoods other than fishing. This underlies the need for any reforms that would have to be implemented to be based within a broad human development approach. Despite the hardship that bold action is likely to cause, initiating these limitations could provide the most best way for dealing with the excess effort. Continuing on the current path can only lead to biological and economic collapse of the fishery in Southern Lake Malawi as has happened in Lake Malombe (FAO, 1993; Hara et al., 2002; Tweddle et al., 2015). A solution that we propose is the introduction of a RBM approach buttressed by the 'rights based human development approach' for southern Lake Malawi and also eventually for the rest of Lake Malawi and other water bodies.

\subsection{An alternative approach to fisheries management in southern Lake Malawi - RBM}

While taking cognizance of the fact that some form of rights based approach has been attempted under co-management arrangements that had been introduced in the 1990s such as on Lake Malombe and Lake Chilwa (the problems that have been encountered around implementing co-management in Malawi have been well documented by, among others, Hara et al, 2002; Hara and Raakjaer Nielsen, 2003; Hara, 2008; Weyl, 2008; Njaya, 2007; Béné et al., 2009; Njaya, et al., 2012; and Nunan et al., 2015), we are arguing for and advocating a bold fresh approach since all the key stakeholders have little choice other than taking drastic measures if the current decline in the fisheries is to be arrested and reversed. Crucial and important is that participants at the national workshops also articulated the key underlying problems outlined in the preceding section (5) and expressed the need and desire for decisive action.

Assuming that a system for determining the annual TAC could be developed and rights assigned to a defined number of rights holders, vessels and gears in the small-scale fisheries the next challenge would be how to implement controls that could ensure adherence to these limits on effort and output. The current system whereby fishers can land wherever they want would have to be abolished. In this context, landing points will have to be established where fishers should land. The field recorders will have to be stationed at these specific points to record the amount of catch by each rights holder and deduct from their annual quota - just like it is done in other quota based management systems. The research section could also use these same points to collect systematic catch and biological data for estimating biomass and MSYs for the target species. 
Inspectors and community-level committees can then also check both the gear and catch to ensure that the right gears are being used in terms of technical specifications and also, under-sized fish is not being landed. Establishment of designated landing points could also help with more efficient gear licensing, thereby improving revenue collection (and hopefully provide justification for improved funding for management activities for the DoF as argued under section 5.4 above). In addition, centralized points could also facilitate improved provision of infrastructure and systems for basic human development needs for fishing communities. Such a system could also reduce the need for monitoring and surveillance out on the lake if all boats will have to call in at designated landing points to have their catch recorded. The system of establishing designated landing points would require investment in landing infrastructure and also monitoring that this system is not being infringed. One problem is that this could run counter to the benefits that chiefs derive from fishing activities in their areas from small-scale fishers. As part of cultural benefit systems, chiefs require that fishers give them honorarium for using beaches in their areas for their fishing activities (Hara et al., 2002; Njaya et al., 2012). Establishment of government landing points could deny them such benefits. Their support for this new system would therefore be crucial, if they are not to run parallel systems that would allow fishers to avoid landing at designated points.

The other major challenge would be the institutional arrangements for RBM - what organizational structures should this be built around and is the current policy and legislation enabling enough to facilitate and promote this approach? While it would help if government re-established some of the landing points that it had built in the 1980s and 1990 as area extension centers, ideally the landing points could be built around BVCs. Fishing rights for specific areas could then be channeled through BVCs that would then be responsible for registering rights holders. In collaboration with government, BVCs could be responsible for controlling and monitoring number of vessels, gears and catches (output). Fishers and BVCs will also need to work hand-inhand with the DoF in monitoring and enforcing the exclusive rights and regulations out on the lake as most of the important gears fish offshore. Also important will be to ensure that the FCMA is revised towards strengthening real devolution of authority and responsibility to BVCs and in effect, fishers (Hara, 2008; Weyl, 2008). As it stands, the current FCMA does not go far enough for facilitating RBM.

\subsection{Selection criteria for rights holders}

The selection of rights holders would have to be based on criteria developed and agreed upon by the fishing communities. There are many issues around criteria for selection of 
rights holders that would have to be developed through detailed consultations and consensus with fishers and other stakeholders. Some of such criteria could be as follows:

a) Should this be based on residency in a particular fishing area along the lakeshore at traditional authority (village) level or ward council level?;

b) How far out inland from the lake level would qualify one as belonging to a fishing community?;

c) Will rights be based on the vessel, gear or given to an individual?;

d) What should be the criteria for the size of the quota for each specific rights holder;

e) Will rights be based on basket of species or species specific?;

f) How long will such rights be and will the rights be transferable?;

g) If transferable, under what circumstances would they be transferable and to whom can they be transferred;

h) Will rights be tradable (if so what would be the conditions for trading rights)?;

i) Under what circumstances would a rights-holder lose rights (e.g. severe infringement of regulations, non-operationalization of right, etc.?);

j) Will such rights be based on geographic territory or apply to the whole of Lake Malawi?;

k) What will be the role of fishers out on the lake in monitoring one another; and

l) What will be the role of BVCs and traditional authorities at landing points in their areas in ensuring that the provisions of the system are being adhered to?

This is not an exhaustive list of possible questions and issues that would need to be dealt with when developing criteria for the issuing of rights in a right based system. What this short list of possible issues shows is that this process would need the participation and buy-in of those that it proposes to primarily regulate, apply to and benefit - the fishing communities. Further to that would be the need to develop management plans with input from the fishing communities and other stakeholders within a particular area and district before a formal approval by the District Council as by-laws as stipulated under administrative decentralisation.

\section{Conclusion}

The historical policy approaches and the general characteristics of small-scale fisheries would make introducing RBM difficult since fishers have developed the perception that access to fishing, fishing intensity and effort types should not be controlled as these had never been controlled in the past. As a result, there has been fear of embracing difficult choices for the changes that they realize would be necessary if the fishery is to move 
towards sustainable utilization. In this context, there has been a general reluctance to grapple with and embrace novel restrictive measures, particularly those that would introduce limited access, limited effort, limits on output and also possibly zonal based fishing rights. At the same time the majority of fishers admit that currently, there is over-capacity in terms of effort and levels of output for most species, and that without instituting measures such as those based on a RBM approach, decline of the fishery is likely to continue leading to increased dissipation of rent.

We have attempted to suggest a system for implementing a RBM approach for southern Lake Malawi. Such a system would need to be accepted by fishers (including crew members) and also it will have to be developed in collaboration with the fishers and traditional authorities. The proposed development of the Ecosystem Approach to Fisheries and Aquaculture in the southern Lake Malawi also needs to consider the RBM as part of governance reform for sustainable utilization of the fisheries resources. Critical and important is that fishers, traditional authorities and all other stakeholders realize and accept that the current system cannot continue without detriment to both the resource and the sustainable benefits from the resource that they and their children can derive in future. Herein lays the dilemma and conundrum of achieving sustainable small scale fisheries management in Southern Lake Malawi (and Malawi as a whole) damned if you try to do something about the prevailing situation, damned if you don't do anything about it as eventually non-action will lead to biological and socio-economic collapse of the fishery.

\section{Acknowledgements}

Mafaniso Hara would like to thank the National Research Foundation of South Africa and the University of the Western Cape for funding. The contents of this article though is we the author's sole responsibility. Also thanks to all the interviewees that availed themselves for the research and the two anonymous reviewers. 


\section{References}

Allison, E.H., Ratner, B.D., Asgard, B., Willman, R., Pomeroy, R., Jurien, J., 2012. Rights-based fisheries governance: from fishing rights to human rights. Fish and Fisheries. 13, 14-29.

Arnason, R., 2005. Property Rights in fisheries: Iceland's experience with ITQs. Reviews in Fish Biology and Fisheries. 15, 243-264.

Asada, Y., Hirasawa, Y., Nagasaki, F., 1983. Fishery management in Japan. FAO (Fisheries Technical Paper 238), Rome.

Banda, M.C., Tomasson, T., 1997. Demersal Fish Stocks in Southern Lake Malawi: Stock Assessment and Exploitation. Fisheries Bulletin No. 35. DoF, Lilongwe,

Banda, M.C., Kanyerere, G.Z., Rusuwa, B., 2005. The status of the chambo in Malawi: fisheries and biology. in: Banda MC, Jamu D, Njaya F, Makuwila M, and Maluwa A. (eds.), The chambo restoration strategic plan: National workshop (13-16 May 2003, Mangochi) proceedings. WorldFish Center proceedings. 71, 1- 7 .

Barratt, C., 2012. Netting the benefits now or later? Exploring the relationship between risk and sustainability in Lake Victoria fisheries. In: Bloemertz, L., Doevenspeck, M., Macamo, E., Mu"ller-Mahn, D. (Eds.), Risk and Africa: Multidisciplinary Empirical Approaches. Lit Verlag, Zurich.

Bell, R.J., Collie, J.S., Jamu D., Banda, M., 2012. Changes in the biomass of chambo in the southeast arm of Lake Malawi: A stock assessment of Oreochromis spp. Journal of Great Lakes Research. 38 (4), 720-729.

Béné, C.E., Belal, M.O., Baba, S., Ovie, S., Raji, A., Njaya, F., Na Andi, M., Russell, A., Neiland, A., 2009. Power struggle, dispute and alliance over local resources: analyzing 'Democratic' decentralization of natural resources through the lenses of Africa inland fisheries. World Development. 37, 1935-1950.

Béné, C., B. Hersoug and E. Allison. 2010. Not by rent alone: analysing the pro-poor functions of small-scale fisheries in developing countries. Development Policy Review. 28(3): 325-358.

Bromley, D., 2009. Abdicating responsibility: the deceits of fisheries policy. Fisheries $34(6), 280-302$.

Carruthers, T. R., Punt, A. E., Walters, C. J., MacCall, A., McAllister, M. K., Dick, E.J., Cope , J., 2014. Evaluating methods for setting catch limits in data-limited fisheries. Fisheries Research. 153, 48-68 
Chirwa, W.C., 1995. Fishing Rights, Ecology and Conservation Along Southern Lake Malawi. African Affairs. 95, 1920-1964.

Christy, F.T., 2000. Common Property Rights. An Alternative to ITQs. in: Shotton, R. (ed.), Use of Property Rights in Fisheries Management. FishRights99 Conference Proceedings. FAO (Fisheries Technical Paper 404/1), Rome, pp. 118-135.

Clark, C.W., Munro, G., Sumaila, U.R., 2010. Limits to the privatization of fishery resources. Land Economics. 86(2), 209-218.

Copes, P., Pálsson, G., 2000. Challenging ITQs: Legal and Political Action in Iceland, Canada and Latin America. A Preliminary Overview. in: Johnston, R.S. (ed), IIFET 2000 Proceedings. Corvallis, Oregon, USA, 1-6.

Costello, C., Gaines, S., Lynham, J., 2008. Can catch shares prevent fisheries collapse? Science. 321, 1678-1681.

Davis, A. and K. Ruddle. 2012. Massaging the misery: recent approaches to fisheries governance and the betrayal of small-scale fisheries. Human Organization 71(3): 244254).

Delaney, L., Jamu, D.M., Campbell, C.E., 2007. Abundance and distribution of fish in the Lower Mnembo River, Malawi-Mozambique. Afr. J. Ecol. 3, 390-397.

DoF, 2013a (unpublished). Frame Survey Report for 2003 to 2013. DoF, Capital Hill, Lilongwe.

DoF, 2013b (unpublished). Estimated Annual Catch Report for 1974 to 2012. DoF, Capital Hill, Lilongwe.

Dewees, C.M., 1998. Effects of individual quota systems on New Zealand and British Columbia fisheries. Ecological Applications, Supplement: Ecosystem Management for Sustainable Marine Fisheries. 8, 133-138.

Donda, S., Hara, M., Ngochera, M., Berge, E., 2014. Fragmentation of Resource Management on the Southeast Arm of Lake Malawi: dynamics around fisheries. PLAAS \& Lit verlag, Berlin.

Edwards, M., 2000. The Administration of Fisheries Managed by Property Rights. in: Shotton, R. (ed.), Use of Property Rights in Fisheries Management. FishRights99 Conference Proceedings. FAO (Fisheries Technical Paper 404/1), Rome, pp. 75-88.

Essington, T., 2010. Ecological indicators display reduced variation in North American catch share fisheries. National Academy of Sciences Proceedings. 107(2), 754-759. 
Eythórsson, E., 1996. Theory and practice of ITQs in Iceland: privatization of common fishing rights. Marine Policy. 30, 269-281.

Eythórsson, E., 2000. A decade of ITQ-management in Iceland fisheries: consolidation without consensus. Marine Policy. 24, 483 -492.

FAO, 1992. Fish and Fishery Products (FIDI/C821 Rev. 2): World Apparent Consumption Statistics Based on Food Balance Sheets (1961-1990). FAO, Rome.

FAO, 1993. Fisheries Management Southeast Arm of Lake Malawi, Upper Shire River and Lake Malombe. GOM/FAO/UNDP Chambo Fisheries research Project. FAO (CIFA Technical Paper 21), Rome.

FAO, 2005. Property rights and fisheries management. Issues Fact Sheets. FAO, Rome. downloaded 19.10. 14 from http://www.fao.org/fishery/topic/13335/en. Food and Agriculture Organization of the United Nations, 2012. Voluntary Guidelines on the Responsible Governance of Tenure of Land, Fisheries and Forests in the Context of National Food Security. FAO, Rome.

FAO, 2012. Yearbook of Fishery Statistics summary tables: food balance sheets 2011. FAO, Rome. (ftp://ftp.fao.org/FI/STAT/summary/FBS_bycontinent.pdf)

FAO, 2013. International Guidelines for Securing Sustainable Small-scale Fisheries in the context of Food Security and Poverty Eradication. FAO, Rome.

FAO 2014. The value of African fisheries. FAO Fisheries and Aquaculture Circular No. 1093. FAO, Rome.

Gibbs, M.T., 2009. Individual transferable quotas and the ecosystem-based fisheries management: it's all in the T. Fish and Fisheries. 10, 470-474.

Grafton, R.Q., 1996. Individual transferable quotas: theory and practice. Reviews in Fish Biology and Fisheries. 6, 5-20.

Grafton, R., Kompas, Q.T., Hilborn, R.W., 2007. Economics of overexploitation revisited. Science. 318(5856), 1601.

GoM, 1973. GoM Laws (Cap. 66:05). GoM, Old Parliament, Zomba.

GoM, 1997. Revised Fisheries Act. GoM, Capital Hill, Lilongwe. http://www.malawilii.org/files/mw/legislation/consolidatedact/66:05/fisheries_conservation_management_act_pdf_70735.pdf

GoM, 2000. Conservation and Management (Local Community Participation) Rules. GoM, Capital Hill, Lilongwe. 
GoM, 2009. The Green Belt Initiative: Concept Paper. Ministry of Agriculture and Food Security, Capital Hill, Lilongwe.

GoM, 2012. National Fisheries Policy 2012-2017 (Second Edition). GoM, Capital Hill, Lilongwe. http://www.unpei.org/sites/default/files/event_documents/Fisheries policy Final 2013.11.2012.pdf

Hara, M.M., 2006. Restoring the Chambo in Southern Malawi: Learning from the Past or re-inventing the wheel? Aquatic Ecosystem Health \& Management. 9 (4), 419-432.

Hara, M., 2008. Dilemmas of Democratic Decentralization in Mangochi District, Malawi: Interest and Mistrust in Fisheries Management. Conservation and Society. 6 (1), 74-86.

Hara, M., 2011. Community Response: Decline of the Chambo in Lake Malawi. in: Jentoft, S., Eide, A. (eds.), Poverty Mosaics: Realities and Prospects in Small-scale Fisheries. Springer, Amsterdam, pp. 251-273.

Hara, M.M., 2013. Efficacy of Rights Based Management within Ecosystems Approach to Fisheries in South Africa's small pelagic. African Journal for Marine Science. 35 (3), 315-322.

Hara, M., Donda, S., Njaya, F.J., 2002. Lessons from Malawi's Experience with Fisheries Co-management Initiatives. in: Geheb, K., Sarch, M.T. (eds.), Africa's inland fisheries: the management challenge. Fountain Publishers, Kampala, pp. 31-48.

Hara, M., Jul-Larsen, E., 2003. The "Lords" of Malombe: An Analysis of Fishery Development and Changes in Fishing Effort on Lake Malombe, Malawi. in: Jul-Larsen, E., Kolding, J., Overa, R., Raakjaer Nielsen, J., van Zwieten, P.A.M. (eds.), Management, co-management or no management? Major dilemmas in southern African freshwater fisheries. FAO (Technical Paper 462/2Fisheries), Rome, pp. 179-200.

Hara, M., Nielsen, J.R., 2003. Experiences with fisheries co-management in Africa. in: Wilson, D.C., Nielsen, J.R., Degnbol, P. (Eds.), The Fisheries Co-management Experience: Accomplishments, Challenges and Prospects. Kluwer Academic Publishers. Dordrecht, The Netherlands, pp81-95

Hardin, G., 1968. The Tragedy of the Commons. Science. 162, 1243-1248.

Hatcher, A., Read, A., 2001. The Allocation of Fishing Rights in UK Fisheries. Case Studies on the Allocation of Transferable Quota Rights in Fisheries in: Shotton, R. (ed.), Use of Property Rights in Fisheries Management. FishRights99 Conference Proceedings. FAO (Fisheries Technical Paper 404/1), Rome, pp. 1-14. 
Hecky, R.E., Bootsma, H.A., Kingdon, M.J., 2003. Impact of land use on sediment and nutrient yields to Lake Malawi/Nyasa (Africa). J. Great Lakes Res (Suppl). 29, 139 158.

ICSF. 2007. Siem Reap statement from the workshop on Asserting Rights, Defining Responsibilities: Perspectives from Small-scale Fishing Communities on Coastal and Fisheries Management in Asia. Siem Reap, Cambodia. http:// rights.icsf.net/images/resources/statements/statements/110_Punta_de_Tralca Workshop_Statement_Eng.doc (accessed 25.07.15)

JICA, 2005. National Aquaculture Strategic Plan (NASP) 2006-2015. Working Paper. JICA, Lilongwe.

Jul-Larsen, J. Kolding, R. Overa, J. Raakjaer Nielsen and P. A. M. van Zwieten (eds.). 2003. Management, co-management or no management?: Major dilemmas in southern African freshwater fisheries. FAO Fisheries Technical Paper 462/1 \&2. Rome.

Kanyerere, G.Z., Kaonga, D., Mponda, O., Ngulande, E., 2010. Commercial fishery frame survey. DoF, Lilongwe.

Kapeleta, L., 1973. The coming of the Tonga and the commercialization of fishing', in: Page, M.E., Land and labor in rural Malawi. Rural Africana, XXI.

Lewis, D.S.C., Tweddle, D., 1990. The yield of usipa (Engraulicypris sardella) from Nankumba Peninsula, Lake Malawi (1985-1986). in: Pitcher, T.J., Hollingworth, C.E. (eds.), Collected reports on fisheries research in Malawi. Occasional Papers, Volume 1. Overseas Development Administration, London, pp. 57- 66.

McCay, B.J., Apostle, R., Creed, C.F., 1998. Individual transferable quotas, comanagement and community: lessons from Nova Scotia. Fisheries. 23, 20-24.

Mills, D., Béné, C., Ovie, S, Tafida, A., Sinaba, F., Kodio, A., Russell, A., Andrew, N., Morand, P. and Lemoalle, J. 2011. Vulnerability in African small-scale fishing communities. J. Int. Dev. 23 (2) 308-313.

Mkanda, F.X., 2000. Contribution by farmers' survival strategies to soil erosion in the Linthipe River Catchment: implications for biodiversity conservation in Lake Malawi/Nyasa. Biodiversity and Conservation. 11, 1327-1359.

Newman, D., Berkson, J., Suatoni, L. 2015. Current methods for setting catch limits for data-limited fish stocks in the United States. Fisheries Research. 164, 86-93.

Njyaya, F. 2007. Governance challenges for the Implementation of Fisheries coManagement: Experiences from Malawi. International Journal of the commons 1(1), 137-153. 
Njaya, F., Donda, S., Béné, C. 2012. Analysis of Power in Fisheries Co-Management: Experiences from Malawi. Society and Natural Resources. 25, 652-666.

Nunan, F., Hara, M., Onyango, P., 2015. Institutions and Co-Management in East African Inland and Malawi Fisheries: A Critical Perspective. World Development. 70, 203-214.

OECD, 1997. Towards Sustainable Fisheries: Economic Aspects of the Management of Living Marine Resources. OECD, Paris.

Ostrom, E., 2009. Design principles of robust property rights institutions: what have we learned. in: Ingram, G.K., Hong, Y-H. (eds.), Property rights and land policies. Lincoln Institute of Land Policy. Cambridge, Massachusetts, pp. 25-51.

Pauly, D., 1996. ITQ: the assumptions behind a meme. Reviews in Fish Biology and Fisheries. 6, 109-112.

Pinkerton, E., Edwards, D.N., 2009. The Elephant in the room: the hidden costs of leasing individual transferable fishing quotas. Marine Policy. 33, 707-713.

Ratner, B.D., Allison, E.H., 2012. Wealth, rights, and resilience: an agenda for governance reform in small-scale fisheries. Dev. Policy Rev. 30 (4) 371-398.

Ratner, B., B. Åsgård and E.H. Allison. 2014. Fishing for justice: human Rights, development, and fisheries. Global Environmental Change 2, 120-130

Ruddle, K., Hviding, E., Johannes, R.E., 1992. Marine resources management in the context of customary tenure. Marine Resources Economics. 7(4), 249-273.

Sanchirico, A.N., Wilen, J.E., 2002. The Impacts of Marine Reserves on Limited-Entry Fisheries. Natural Resource Modelling. 15(3), 291-310.

Schlager, E., Ostrom, E., 1992. Property Rights Regimes and Natural Resources. A Conceptual Analysis. Land Economics. 68, 249-62.

Sharma, H. 2011. Securing economic, social and cultural rights of small-scale and artisanal fisherworkers and fishing communities. Maritime Studies, 10(2), 41-61

Shotton, R., 2000. Use of Property Rights in Fisheries Management. in: Shotton, R. (ed.), Use of Property Rights in Fisheries Management. FishRights99 Conference Proceedings. FAO (Fisheries Technical Paper 404/1), Rome, pp. 45-50.

Song, A., Chuenpagdee, R., 2013. The Damage Schedule Approach. in: Bavinck, M., Chuenpagdee R., Jentoft, S., Kooiman, J. (eds.), Governability of fisheries and aquaculture: theory and applications). Springer, Amsterdam, pp. 279-299. 
Suárez, S. M. 2012. The Human Rights Framework in contemporary agrarian struggles. The Journal of Peasant Studies, 40(1), 239-290.

Sumaila, U.R., 2010. A cautionary note on individual transferable quotas. Ecology and Society. 15(3), 36 .

Sumaila, U.R., The, L., Watson, R., Tyedmers, P., Pauly, D., 2008. Fuel price increase, subsidies, overcapacity, and resource sustainability. ICES Journal of Marine Science. 65(6), 832-840.

Sunde, J and H. Sharma. 2012. In Suárez, S. M. 2012. The Human Rights Framework in contemporary agrarian struggles. The Journal of Peasant Studies, 4O(1), 280-285.

Thompson, A.B., Allison, E.H., Ngatunga, B.P., 1996. Distribution and breeding biology of offshore pelagic cyprinids and catfish in Lake Malawi/Niassa. Env. Biol. Fish. 47, 2742.

Thompson, A.B., Allison, E.H., 1997. Potential yield estimates of unexploited pelagic fish stocks in Lake Malawi. Fish. Man. Ecol. 4, 31-48.

Townsend, R.E., 1990. Land Economics. 66(4), 359-378.

Turner, G.F., 1995. Management, conservation and species changes of exploited fish stocks in Lake Malawi. in: Pitcher, T.J., Hart, P.J.B. (eds.), The Impact of Species Changes in African Lakes. Chapman \& Hall, London, pp. 365-395.

Turner, G.F., Tweddle, D., Makwinja, R.D., 1995. Changes in demersal cichlid communities as a result of trawling in southern Lake Malawi. in: Pitcher, T.J., Hart, P.J.B. (eds.), The Impact of Species Changes in African Lakes. Chapman and Hall, London, pp. 397-412.

Tweddle D., Cowx, I. G., Peel, R. A., Weyl, O. L. F., 2015. Challenges in fisheries management in the Zambezi, one of the great rivers of Africa. Fisheries Management and Ecology. 22, 99-111.

Weyl, O., 2008. In: Wijeyaratne, M.J.S., Amarasinghe, U.S. (eds.), Lessons learnt from 10-years of co-manageemnt in Lake Malombe, Malawi, Africa and their applicability to Sri Lanka's pereninial reservoirs. Pariticpatory Approaches to Reservoir Fisheries Management: Issues, Challenges and Policies. Sri Lanka Association for Fisheries and Aquaculture Resources. Colombo, p1-16

Weyl, O.L.F., Kazembe, J., Booth, A.J., Mandere, D.S., 2004. An assessment of a light attraction fishery in southern Lake Malawi. African Journal of Aquatic Science. 29(1), 111. 
Weyl, O.L.F., Nyasulu, T., Rusuwa, B., 2005. Assessment of catch, effort and species changes in the pair trawl fishery of southern Lake Malawi, Malawi, Africa. Fish. Man. Ecol. 12, 395-402.

Weyl, O.L.F., Ribbink, A.J., Tweddle, D., 2010. Lake Malawi: fishes, fisheries, biodiversity, health and habitat. Aquatic Ecosystem Health \& Management. 3, 241-254.

Wilen, J.E., Cancinoy, J., Uchida, H., 2012. The Economics of Territorial Use Rights Fisheries, or TURFs. Review of Environmental Economics and Policy. 6 (2), 237-257.

World Bank, 2004. Saving Fish and Fishers. World Bank, Washington D. C.

World Bank, 2009. The sunken billions: the economic justification for fisheries reform. World Bank, Washington D.C.

World Bank, 2012. The Republic of Malawi Joint IDA-IMF Staff Advisory Note on the Second Malawi Growth and Development Strategy (Report No. 69134-MW). World Bank, Washington D.C. 